Review

\title{
Effects of the polyunsaturated fatty acids, EPA and DHA, on hematological malignancies: a systematic review
}

\author{
Milad Moloudizargari ${ }^{1}$, Esmaeil Mortaz $2,3,4$, Mohammad Hossein Asghari ${ }^{5}$, Ian M. \\ Adcock ${ }^{6}$, Frank A. Redegeld ${ }^{4}$ and Johan Garssen ${ }^{4,7}$ \\ ${ }^{1}$ Department of Immunology, School of Medicine, Student Research Committee, Shahid Beheshti University of Medical \\ Sciences, Tehran, Iran \\ ${ }^{2}$ Department of Immunology, School of Medicine, Shahid Beheshti University of Medical Sciences, Tehran, Iran \\ ${ }^{3}$ Clinical Tuberculosis and Epidemiology Research Center, National Research Institute for Tuberculosis and Lung Disease \\ (NRITLD), Shahid Beheshti University of Medical Sciences, Tehran, Iran \\ ${ }^{4}$ Division of Pharmacology, Utrecht Institute for Pharmaceutical Sciences, Faculty of Science, Utrecht University, Utrecht, \\ Netherlands \\ ${ }^{5}$ Department of Pharmacology, Faculty of Medicine, Babol University of Medical Sciences, Babol, Iran \\ ${ }^{6}$ Cell and Molecular Biology Group, Airways Disease Section, National Heart and Lung Institute, Imperial College London, \\ Dovehouse Street, London, UK \\ ${ }^{7}$ Nutricia Research Centre for Specialized Nutrition, Utrecht, Netherlands \\ Correspondence to: Esmaeil Mortaz, email: e.mortaz@uu.nl
}

Keywords: omega-3; eicosapentaenoic acid; docosahexaenoic acid; apoptosis; fish oil

Received: August 30, $2017 \quad$ Accepted: January 21, $2018 \quad$ Published: February 05, 2018

Copyright: Moloudizargari et al. This is an open-access article distributed under the terms of the Creative Commons Attribution License 3.0 (CC BY 3.0), which permits unrestricted use, distribution, and reproduction in any medium, provided the original author and source are credited.

\section{ABSTRACT}

Omega-3 polyunsaturated fatty acids (PUFAs) have well established anti-cancer properties. Eicosapentaenoic acid (EPA) and docosahexaenoic acid (DHA) are among this biologically active family of macromolecules for which various anti-cancer effects have been explained. These PUFAs have a high safety profile and can induce apoptosis and inhibit growth of cancer cells both in vitro and in vivo, following a partially selective manner. They also increase the efficacy of chemotherapeutic agents by increasing the sensitivity of different cell lines to specific anti-neoplastic drugs. Various mechanisms have been proposed for the anti-cancer effects of these omega-3 PUFAs; however, the exact mechanisms still remain unknown. While numerous studies have investigated the effects of DHA and EPA on solid tumors and the responsible mechanisms, there is no consensus regarding the effects and mechanisms of action of these two FAs in hematological malignancies. Here, we performed a systematic review of the beneficial effects of EPA and DHA on hematological cell lines as well as the findings of related in vivo studies and clinical trials. We summarize the key underlying mechanisms and the therapeutic potential of these PUFAs in the treatment of hematological cancers. Differential expression of apoptosis-regulating genes and Glutathione peroxidase 4 (Gp-x4), varying abilities of different cancerous and healthy cells to metabolize EPA into its more active metabolites and to uptake PUFAS are among the major factors that determine the sensitivity of cells to DHA and EPA. Considering the abundance of data on the safety of these FAs and their proven anti-cancer effects in hematological cell lines and the lack of related human studies, further research is warranted to find ways of exploiting the anticancer effects of DHA and EPA in clinical settings both in isolation and in combination with other therapeutic regimens. 


\section{INTRODUCTION}

Omega 3 polyunsaturated fatty acids (PUFAs) are members of a large group of fatty acids (FAs) possessing multiple double bonds in their structures [1]. These biologically active macromolecules are well known to have various vital physiological roles required for proper functioning of cells [1]. Many effects of these FAs are mediated by their more active longer chain metabolites which act via changing the plasma membrane composition, producing various inflammatory mediators and altering the expression of different genes. Eicosapentaenoic acid (EPA) and docosahexaenoic acid (DHA) are among the very long chain PUFAs for which various health benefits have been shown. These FAs decrease the risk of cardiovascular diseases by regulating the contributing risk factors including blood pressure, blood coagulation, cardiac rhythm and heart rate among many others [2-4]. Anti-inflammatory [5] and immune modulatory effects $[1,6]$ and the regulation of several metabolic pathways by these FAs have been also reported giving them the potential to be therapeutically exploited in the treatment of inflammatory diseases, metabolic disorders such as type-2 diabetes and immunocompromising conditions.

An epidemiological study in 1997 revealed that decreased incidence of colorectal cancer among South African West Coast fishermen who generally had a less healthy diet in comparison with the urban population, could be attributed to presence of fish oil in their diet [7]. Dietary intake of omega-3 FAs has been also shown in human studies to inversely correlate with the overall risk of different types of malignancies such as colorectal, prostate and breast cancer [8-10]. A substantial number of in vitro studies on cancer cell lines as well as studies on animal models of cancers have shown the antiproliferative, apoptotic, cytotoxic, and anti-metastatic properties of DHA and EPA [11]. Keeping in mind that ROS can decrease cancer cell survival [12], different mechanisms have been suggested for the anti-cancer effects of DHA and EPA such as induction of ROS and consequent peroxidation of lipids [13,14], changing the composition of the plasma membrane and lipid rafts $[15,16]$, affecting the mitochondrial membrane potential [17] and epigenetic alteration of genes involved in apoptosis [18].

Potential drug sensitizing effects of DHA and EPA have also been reported in numerous studies such that low amounts of these two FAs in combination with anticancer agents can result in increased sensitivity of cancer cells to anti-neoplastic agents even in some drug-resistant cell lines [19]. Recent evidence also points at the potent and at the same time selective actions of EPA and DHA on multiple myeloma cell lines which had not been previously investigated [20]. Most of the well-established anti-cancer effects of these PUFAs have been studied in solid tumors. Although ample data is available regarding the effects of
DHA and EPA on haematological malignancies, still there is ambiguity regarding the exact mechanisms responsible for their actions on haematological cancers. In the present study, we systematically reviewed the effects of DHA and EPA on different leukemic and multiple myeloma cells with particular focus on the potential mechanisms of action. Moreover, we review the current evidence on the bioavailability and applicability of EPA and DHA for their clinical use in the context of haematological cancers.

\section{Search strategy and data extraction}

In order to access the relevant data, a literature search was performed based on the Preferred Reporting Items for Systematic Reviews and Meta-Analyses (PRISMA) guidelines. The authors explored the Web of Science, Pubmed, and Scopus databases using the following keywords: "Leukemia" AND "DHA OR EPA", "Multiple Myeloma" AND "DHA OR EPA", and "Lymphoma" AND "DHA OR EPA". EPA and DHA are abbreviations which are frequently used to show eicosapentaenoic and docosahexaenoic acids, respectively. In total, 674 published papers were retrieved after applying the filter of "articles in English only". After removing the duplicates, the articles were screened based on their relevance to the topic and all irrelevant papers were excluded. The studies where the term "lymphoma" was detected in the context of the extended form of bcl2 (B cell lymphoma 2) and were found irrelevant to the topic were also removed. The full texts of the remaining papers $(n=150)$ were further evaluated for the eligibility and relevance of their findings. All discrepancies were subjected to discussion until proper conclusions were made in each case. A final number of 87 articles met all the inclusion criteria and were found suitable to be reviewed (Figure 1). Data extraction was performed and the key findings of all previous studies were presented as tables and illustrations (Table 1 and Figure 1). The results were organized in separate sections including in vitro and in vivo studies and drug sensitizing effects. Finally, the overall results were subjected to discussion in which the possible mechanisms of selective action of EPA and DHA on neoplastic cells and the feasibility of their clinical usage were explained and a conclusion was finally drawn.

\section{IN VITRO STUDIES ON EPA AND DHA}

\section{Anti-proliferative and differentiation inducing effects}

Omega-3 FAs have been shown to have strong antiproliferative and differentiation promoting effects [21, 22]. A natural lipid preparation rich in EPA and DHA (45.3\% of the whole preparation) showed prominent anti-proliferative effects in promyelocytic leukemia (HL$60)$ cells. Separate treatment with pure EPA and DHA 
also inhibited the proliferation of these cells by 11.3 and $19.3 \%$, respectively. However, these effects were more pronounced when they were used in combination with other fatty acids such as conjugated linoleic acid (CLA) [23]. DHA (10-50 $\mu \mathrm{M})$, in combination with $\mathrm{As}_{2} \mathrm{O}_{3}$, induced cell death in HTLV-1-immortalized cells via decreasing mitochondrial membrane potential in a caspase- and PARP-1-independent pathway. This suggested a necrotic cytotoxic effect rather than apoptotic cell death [24]. A study on HL-60 leukemia cells showed that EPA $(10 \mu \mathrm{M})$ is a potent inducer of ROS production and myeloid leukemia cell differentiation which gives it the ability to potentiate the differentiation-inducing effect of 12-O-tetradecanoylphorbol-13-acetate (TPA) [25]. The proliferation of monocytic U937-1 cells has been also shown to be inhibited by EPA at a minimal concentration of $60 \mu \mathrm{M}$ which was accompanied with apoptosis induction at higher concentrations of 120 and $240 \mu \mathrm{M}$. However, in contrast to the results of a majority of studies, these effects were not attributable to the well-established peroxidation mechanisms since the addition of antioxidant agents did not interfere with the anti-proliferative effects of EPA [26]. A previous study on the mouse myeloma cells (SP 2/0) had also shown that EPA $(5-40 \mu \mathrm{g} / \mathrm{mL})$ and to a lower extent DHA exert anti-proliferative effects on this cell type which could be roughly imputed to their lipid peroxidation effects. Complete blockade of this effect by superoxide dismutase (SOD) and cyclooxygenase and lipooxygenase inhibitors revealed a role for superoxides as well as prostaglandins and leukotrienes [27]. A study on HL-60 leukemia cells evaluated the effects of EPA in combination with linolenic acid (GLA) on pulmonary inflammation. EPA (50-100 $\mu \mathrm{M})$ noticeably increased apoptosis and reduced cell viability in HL-60 cells. This was associated with a significantly enhanced rate of necrosis [28]. DHA (10 $\mu \mathrm{M})$ also induced apoptosis and reduced cell viability in the primary cells of CLL patients in a concentration- and time-dependent manner

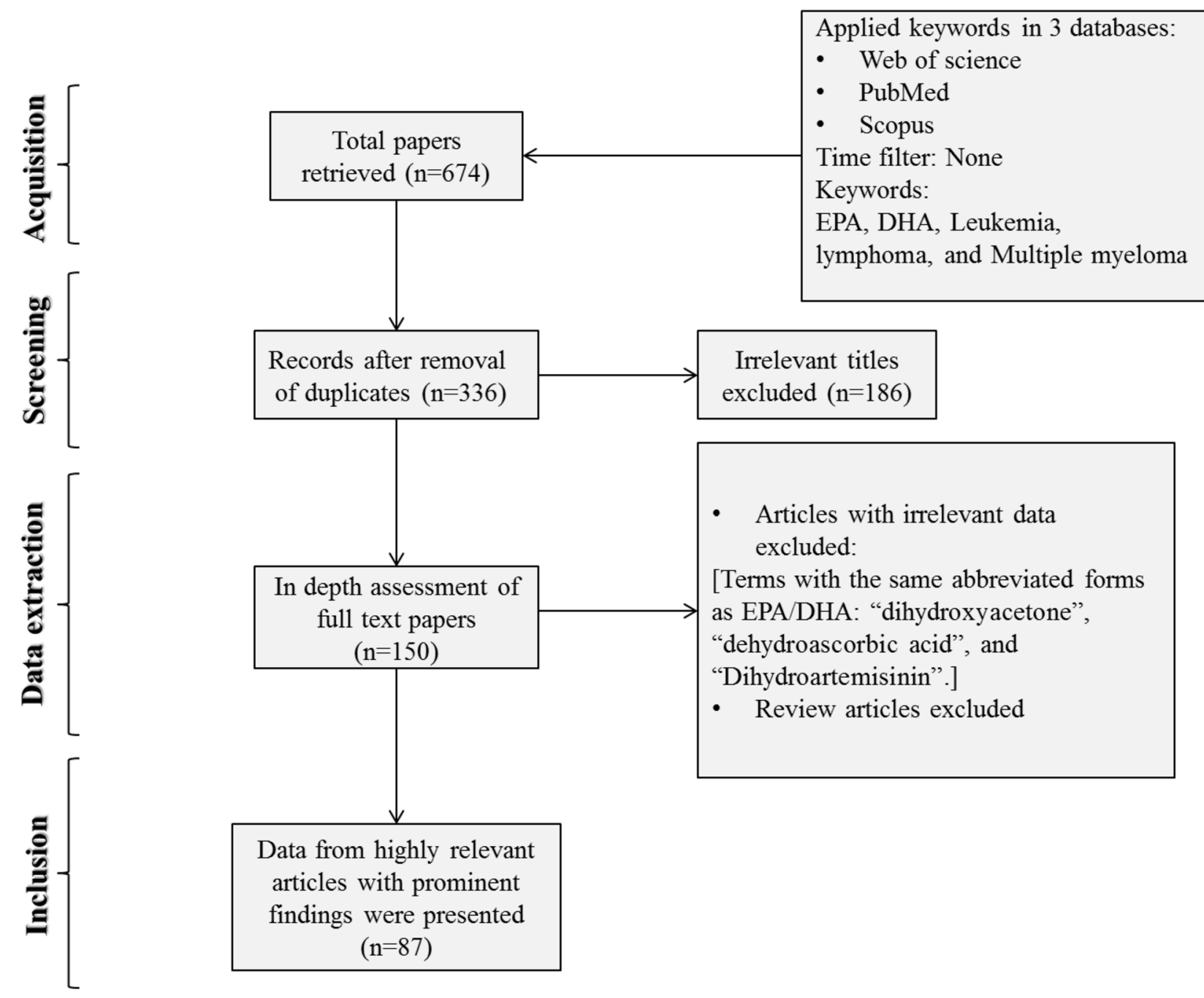

Figure 1: Flow diagram of the search strategy. "Leukemia" AND "DHA OR EPA" and "Multiple Myeloma" AND "DHA OR EPA" were searched in three databases of Web of Science, Pubmed, and Scopus. Finally 133 papers were deemed eligible to be reviewed. 
Table 1: The effects of EPA and DHA treatment on different cell lines and the suggested mechanisms

\begin{tabular}{|c|c|c|c|c|c|c|c|}
\hline $\begin{array}{l}\text { Cell line } \\
\text { animal model }\end{array}$ & Specification & EPA & DHA & $\begin{array}{c}\text { Most } \\
\text { effective } \\
\text { dosage(s) }\end{array}$ & $\begin{array}{l}\text { Incubation } \\
\text { time(s) }\end{array}$ & Outcomes & Reference \\
\hline U 266 & $\begin{array}{l}\text { B lymphocyte } \\
\text { (lymphoblast) }\end{array}$ & $*$ & $*$ & $\begin{array}{c}50 \mu \mathrm{M} \\
100 \mu \mathrm{M}\end{array}$ & & $\begin{array}{l}\text { Apoptosis induction, Drug } \\
\text { sensitizing (Bortezomib), No }\end{array}$ & {$[20]$} \\
\hline L363 & $\begin{array}{l}\text { plasma cell } \\
\text { leukemia }\end{array}$ & $*$ & $*$ & & & $\begin{array}{l}\text { effect on normal PBMCs } \\
\text { Caspase } 3 \text { activation, } \\
\text { Hypoxia modulation, NF-kB }\end{array}$ & \\
\hline OMP-1/2 & $\begin{array}{l}\text { multiple } \\
\text { myeloma }\end{array}$ & $*$ & $*$ & & & $\begin{array}{l}\text { inhibition, Mitochondrial } \\
\text { perturbation ( } \uparrow \text { mitochondrial } \\
\text { membrane potential }(\Delta \Psi \mathrm{m})) \text {, } \\
\text { Upregulation of genes } \\
\text { involved in oxidative stress }\end{array}$ & \\
\hline U937 & $\begin{array}{l}\text { Monocytic } \\
\text { leukemia }\end{array}$ & & $*$ & $\begin{array}{l}10 \mu \mathrm{M} \\
20 \mu \mathrm{M}\end{array}$ & & $\begin{array}{l}\text { Apoptosis induction, } \\
\text { Caspase } 3 \text { activation } \\
\text { and ROS generation as a } \\
\text { result of: } \uparrow[\mathrm{Ca} 2]_{\mathrm{i}} \text { via PLC/ } \\
\mathrm{IP}_{3} \text { pathway and PKC } \gamma / \delta \\
\text { activation }\end{array}$ & [47] \\
\hline Jurkat & Human T cells & $*$ & $*$ & $\begin{array}{l}10 \mu \mathrm{M} \\
20 \mu \mathrm{M}\end{array}$ & & $\begin{array}{l}\uparrow[\mathrm{PH}]_{\mathrm{l}} \text {, simple diffusion, } \\
\text { (flip-flop) of the fatty acid, } \\
\text { occurring in phospholipid } \\
\text { bilayers of the plasma } \\
\text { membrane (the long-lasting } \\
\text { acidification was dependent } \\
\text { on increases in }[\mathrm{Ca} 2]_{\mathrm{i}} \text { ) }\end{array}$ & [48] \\
\hline Molt-4 & $\begin{array}{l}\text { Leukemic cell } \\
\text { line }\end{array}$ & $*$ & $*$ & $5-10-20 \mu \mathrm{g}$ & & $\begin{array}{l}\text { Antiproliferative/cytotoxic } \\
\text { effect in both normal and } \\
\text { leukemic lymphocytes } \\
\text { (concentration dependent) } \\
\uparrow I L-2 \text { (in leukemic cells), } \\
\downarrow \mathrm{IL}-2 \text { (in normal cells), Free } \\
\text { radical generation ( } \uparrow \mathrm{SO}_{2}^{-} \text {and } \\
\text { lipid peroxidation ( } \uparrow \mathrm{MDA} \text { ) }\end{array}$ & {$[84]$} \\
\hline HL-60 & $\begin{array}{l}\text { Human } \\
\text { promyelocytic } \\
\text { leukemia cells }\end{array}$ & * & $*$ & $60 \mu \mathrm{M}$ & $6,12 \mathrm{~h}$ & $\begin{array}{l}\text { Growth inhibition and } \\
\text { apoptosis induction, ROS } \\
\text { generation, } \\
\text { Activation of caspase-like } \\
\text { proteases }(3,6,8 \text {, and } \\
\text { 9-not } 1) \text {, Activation of } \\
\text { Bid cleavage, Decreasing } \\
\text { mitochondrial membrane } \\
\text { potential, Cytochrome c } \\
\text { release from mitochondria, } \\
\text { Surfactant effect on } \\
\text { membrane }\end{array}$ & {$[17]$} \\
\hline HL-60 & $\begin{array}{l}\text { Human } \\
\text { promyelocytic } \\
\text { leukemia cells }\end{array}$ & $*$ & $*$ & $\begin{array}{l}\text { As parts } \\
\text { of lipid } \\
\text { preparations }\end{array}$ & NM & $\begin{array}{l}\text { Antiproliferative effect } \\
\text { NM }\end{array}$ & [23] \\
\hline
\end{tabular}

(continued) 


\begin{tabular}{|c|c|c|c|c|c|c|c|}
\hline $\begin{array}{l}\text { Cell line } \\
\text { animal model }\end{array}$ & Specification & EPA & DHA & $\begin{array}{c}\text { Most } \\
\text { effective } \\
\text { dosage(s) }\end{array}$ & $\begin{array}{l}\text { Incubation } \\
\text { time(s) }\end{array}$ & Outcomes & Reference \\
\hline U937 & $\begin{array}{l}\text { promonocytic } \\
\text { cell line }\end{array}$ & $*$ & & $100 \mu \mathrm{M}$ & 1,3 , and $24 \mathrm{~h}$ & $\begin{array}{l}\text { Regulating gene expression } \\
\uparrow \text { monocytic (leukemia) cell } \\
\text { differentiation, Proliferation } \\
\text { inhibition, } \\
\uparrow \text { demethylation of a specific } \\
\text { CpG site in interon } 1 \text { on } \\
\text { H-Ras gene, } \\
\uparrow H-\text { Ras isoform mRNA and } \\
\text { protein expression } \\
\uparrow \text { active phosphorylated } \\
\text { forms of C/EBP } \beta \text { and } \\
\text { ERK1/2, } \\
\uparrow \text { proteins expression of } \\
\text { CCAAT/enhancer-binding } \\
\text { proteins (C/EBP and C/ } \\
\text { EBP), PU.1, and c-Jun } \\
\text { (myeloid lineage-specific } \\
\text { transcription factors) } \rightarrow \\
\uparrow \text { expression of M-CSF } \\
\text { recepror }\end{array}$ & {$[18,46]$} \\
\hline $\begin{array}{l}\text { HL-60 and } \\
\text { K-562 }\end{array}$ & $\begin{array}{l}\text { Human acute } \\
\text { promyelocytic } \\
\text { leukemia HL- } \\
60 \text { and } \\
\text { chronic } \\
\text { myelogenous } \\
\text { leukemia } \\
\text { K-562 } \\
\text { cell lines, } \\
\text { respectively }\end{array}$ & $*$ & & NM & $24 \mathrm{~h}$ & $\begin{array}{l}\text { Changes in cell cycle: } \uparrow \mathrm{G} 0 / \\
\mathrm{G} 1, \downarrow \mathrm{G} 2 / \mathrm{M} \\
\uparrow \mathrm{Necrosis} \\
\uparrow \text { Apoptosis (only in HL-60) } \\
\uparrow \mathrm{bcl}-2 \text { expression }\end{array}$ & [36] \\
\hline $\begin{array}{l}\text { HL-60 and } \\
\text { K-562 }\end{array}$ & $\begin{array}{l}\text { Human acute } \\
\text { promyelocytic } \\
\text { leukemia HL- } \\
60 \text { and } \\
\text { chronic } \\
\text { myelogenous } \\
\text { leukemia } \\
\text { K-562 } \\
\text { cell lines, } \\
\text { respectively }\end{array}$ & $*$ & & $\begin{array}{c}40,60 \text { and } \\
120 \mu \mathrm{M}\end{array}$ & 24 and $72 \mathrm{~h}$ & $\begin{array}{l}\uparrow \text { Necrosis } \\
\uparrow A \text { poptosis (only in HL-60) } \\
\text { Independent of DNA } \\
\text { fragmentation }\end{array}$ & {$[38]$} \\
\hline HL-60 & $\begin{array}{l}\text { Human acute } \\
\text { promyelocytic } \\
\text { leukemia }\end{array}$ & & $*$ & $10-160 \mu \mathrm{M}$ & $\begin{array}{c}24,48 \text { and } \\
72 \mathrm{~h}\end{array}$ & $\begin{array}{l}\uparrow \text { Apoptosis } \\
\downarrow \text { Proliferation } \\
\text { Phosphorylation-dependent } \\
\text { inactivation of Rb protein } \\
\text { Inducing cell cycle arrest at } \\
\text { G0/G1 phase } \\
\uparrow \text { Expression of E2F- } 6 \text { and } \\
\text { Bax }\end{array}$ & [41] \\
\hline
\end{tabular}

(continued) 


\begin{tabular}{|c|c|c|c|c|c|c|c|}
\hline $\begin{array}{l}\text { Cell line } \\
\text { animal model }\end{array}$ & Specification & EPA & DHA & $\begin{array}{c}\text { Most } \\
\text { effective } \\
\text { dosage(s) }\end{array}$ & $\begin{array}{l}\text { Incubation } \\
\text { time(s) }\end{array}$ & Outcomes & Reference \\
\hline $\begin{array}{l}\text { CEM, HL- } \\
\text { 60, MM1.R, } \\
\text { and MM1.S }\end{array}$ & $\begin{array}{l}\text { T-cell } \\
\text { leukemia, } \\
\text { myeloid } \\
\text { leukemia, } \\
\text { myeloma, and } \\
\text { myeloma, } \\
\text { respectively }\end{array}$ & & $*$ & $100 \mu \mathrm{M}$ & $16 \mathrm{~h}$ & $\begin{array}{l}\uparrow \text { Sensitivity to DHA } \\
\text { cytotoxic effects } \\
\downarrow \text { GP-x4 expression }\end{array}$ & [66] \\
\hline Raji & $\begin{array}{l}\text { human B-cell } \\
\text { lymphoblastoid } \\
\text { line }\end{array}$ & & $*$ & $100 \mu \mathrm{M}$ & $72 \mathrm{~h}$ & $\begin{array}{l}\text { Synergizes the effect of } \\
\text { clioquinol with regard to the } \\
\text { following parameters: } \\
\uparrow \text { Apoptosis } \\
\downarrow \text { Cell viability } \\
\downarrow \text { NF- } \mathrm{B} \text { activity } \\
\downarrow \text { Levels of Akt, p- } 65 \text { and } \\
\text { Bcl-2 }\end{array}$ & [68] \\
\hline $\begin{array}{l}\text { EHEB, } \\
\text { MEC-2 } \\
\text { JVM-2 }\end{array}$ & $\begin{array}{l}\text { B-CLL- } \\
\text { derived cell } \\
\text { lines } \\
\text { B-PLL-derived } \\
\text { cell line }\end{array}$ & $*$ & $*$ & $\begin{array}{c}55,75, \text { and } \\
100 \mu \mathrm{M}\end{array}$ & $72 \mathrm{~h}$ & $\begin{array}{l}\downarrow \text { Cell viability } \\
\uparrow \text { Lipid peroxidation } \\
\uparrow R O S \text { production } \\
\text { Cell cycle arrest in G2/M }\end{array}$ & [85] \\
\hline $\begin{array}{l}\text { C57/BL6 } \\
\text { mouse }\end{array}$ & $\begin{array}{l}\text { Receiving } \\
\text { transplantation } \\
\text { of HSCs } \\
\text { expressing } \\
\text { Bcr-Abl (CML } \\
\text { model) } \\
\text { AML model }\end{array}$ & $*$ & & $\begin{array}{c}1.8 \% \text { of total } \\
\text { diet energy }\end{array}$ & 8 weeks & $\begin{array}{l}\downarrow \text { LSC population } \\
\downarrow \text { Leukocytosis } \\
\downarrow \text { Splenomegaly } \\
\downarrow \text { Leukemia burden } \\
\text { Via production of } \Delta 12-\mathrm{PGJ} 3 \\
\text { Blocked by indomethacin } \\
\text { and HQL-79 }\end{array}$ & {$[52]$} \\
\hline U937-1 & $\begin{array}{l}\text { Monocytic cell } \\
\text { line }\end{array}$ & $*$ & & $\begin{array}{c}60,120 \text { and } \\
240 \mu \mathrm{M}\end{array}$ & $72 \mathrm{~h}$ & $\begin{array}{l}\downarrow \text { Cell viability and } \\
\text { proliferation }(60 \mu \mathrm{M}), \\
\uparrow \text { Apoptosis }(120 \text { and } 240 \\
\mu \mathrm{M}), \\
\uparrow \text { Lipid droplet accumulation, } \\
\uparrow \mathrm{CD} 23 \text { expression, } \\
\text { Lipid peroxidation- } \\
\text { independent mechanisms }\end{array}$ & [26] \\
\hline $\begin{array}{l}\text { Raji, Ramos, } \\
\text { U937-GTB, } \\
\text { U937-1 and } \\
\text { Mono Mac-6 }\end{array}$ & $\begin{array}{l}\text { Highly } \\
\text { sensitive }\end{array}$ & $*$ & $*$ & $\begin{array}{c}30,60 \text { and } \\
120 \mu \mathrm{M}\end{array}$ & $24 \mathrm{~h}$ and $72 \mathrm{~h}$ & $\begin{array}{l}\uparrow \text { Apoptosis and necrosis } \\
\text { (EPA) } \\
\downarrow \text { Cell multiplication } \\
\uparrow T A G-\text { rich lipid droplets }\end{array}$ & {$[40,71]$} \\
\hline $\begin{array}{l}\text { Reh, Molt- } \\
\text { 4, Jurkat, } \\
\text { K-562, and } \\
\text { KG1-a }\end{array}$ & $\begin{array}{l}\text { Moderately } \\
\text { sensitive }\end{array}$ & $*$ & $*$ & $\begin{array}{c}50 \text { and } 120 \\
\mu \mathrm{M}\end{array}$ & & $\begin{array}{l}\text { (EPA) } \\
\uparrow L i p i d \text { peroxidation } \\
\text { Reversible by Vitamin E }\end{array}$ & \\
\hline $\begin{array}{l}\text { KM-3, Nalm- } \\
6 \text { and THP-1 }\end{array}$ & $\begin{array}{l}\text { Slightly } \\
\text { sensitive }\end{array}$ & $*$ & $*$ & $120 \mu \mathrm{M}$ & & & \\
\hline
\end{tabular}

(continued) 


\begin{tabular}{|c|c|c|c|c|c|c|c|}
\hline $\begin{array}{l}\text { Cell line } \\
\text { animal model }\end{array}$ & Specification & EPA & DHA & $\begin{array}{c}\text { Most } \\
\text { effective } \\
\text { dosage(s) }\end{array}$ & $\begin{array}{l}\text { Incubation } \\
\text { time(s) }\end{array}$ & Outcomes & Reference \\
\hline HL-60 & & * & & $60 \mu \mathrm{M}$ & $72 \mathrm{~h}$ & $\begin{array}{l}\uparrow \text { Apoptosis (19\%), } \uparrow \text { Necrosis } \\
(32 \%), \downarrow \text { Proliferation, } \\
\uparrow \text { Differentiation, } \\
\uparrow \text { Lipid peroxidation, } \\
\uparrow \text { Serglycin mRNA levels, } \\
\uparrow \text { Production of superoxide } \\
\text { anions, } \uparrow \text { G1 phase } \\
\text { prolongation }\end{array}$ & [39] \\
\hline HL-60 & $\begin{array}{l}\text { Human } \\
\text { promyelocytic } \\
\text { leukemia }\end{array}$ & $*$ & & $\begin{array}{l}10,20,50, \\
\text { and } 100 \mu \mathrm{M}\end{array}$ & $\begin{array}{l}2,4,8,12, \\
\text { and } 24 \mathrm{~h}\end{array}$ & $\begin{array}{l}\downarrow \text { Cell viability, } \uparrow \text { Apoptosis, } \\
\uparrow \text { Necrosis, Induction of } \\
\text { apoptosis by select dietary } \\
\text { n-3 (EPA) and n- } 6 \text { (GLA) } \\
\text { polyunsaturated fatty acids }\end{array}$ & {$[28]$} \\
\hline $\begin{array}{l}\text { ATCC, CRL- } \\
1923\end{array}$ & $\begin{array}{l}\text { Chronic } \\
\text { lymphocytic } \\
\text { leukemia }\end{array}$ & & $*$ & $10 \mu \mathrm{M}$ & 24 and $48 \mathrm{~h}$ & $\begin{array}{l}\downarrow \text { Cell viability, } \uparrow \text { Apoptosis, } \\
\uparrow \text { Lipid peroxidation and } \\
\text { generation of reactive } \\
\text { oxygen species, } \downarrow \text { Activation } \\
\text { of NF- } \mathrm{B}, \text { Exerts anti- } \\
\text { inflammatory effects after } \\
\text { linking to the G protein- } \\
\text { coupled receptor } 120 \text { in } \\
\text { macrophages }\end{array}$ & [29] \\
\hline $\begin{array}{l}\text { Ramos and } \\
\text { Jurkat cells }\end{array}$ & & $*$ & & $30 \mu \mathrm{M}$ & $24 \mathrm{~h}$ & $\uparrow$ Caspase 3 and 9 activities & [31] \\
\hline HL-60 & $\begin{array}{l}\text { Human } \\
\text { promyelocytic } \\
\text { leukemia }\end{array}$ & & $*$ & $\begin{array}{c}0.4,2,5 \text { and } \\
10 \mu \mathrm{M}\end{array}$ & $24 \mathrm{~h}$ & $\begin{array}{l}\downarrow \text { Sphingosine-induced } \\
\text { apoptosis } \\
\text { Inhibition of cytosolic } \\
\text { phospholipase A2 }\end{array}$ & {$[30]$} \\
\hline $\begin{array}{l}\text { RBL2H3, } \\
\text { HeLa }\end{array}$ & & $*$ & & $\begin{array}{c}25,50,75 \\
\text { and } 100 \mu \mathrm{M}\end{array}$ & $18 \mathrm{~h}$ & $\begin{array}{l}\uparrow \text { Apoptosis, } \uparrow \text { Release of } \\
\text { Cytochrome c, } \uparrow \text { Activation } \\
\text { of caspase- } 3 \text {, } \\
\uparrow \text { Hydroperoxide in } \\
\text { mitochondria }\end{array}$ & {$[32]$} \\
\hline HL-60 & $\begin{array}{l}\text { Human } \\
\text { promyelocytic } \\
\text { leukemia }\end{array}$ & & $*$ & $50 \mu \mathrm{M}$ & $24 \mathrm{~h}$ & $\begin{array}{l}\uparrow \text { Apoptosis, } \uparrow \text { Activation of } \\
\text { caspase- } 3 \text {, Bax-independent } \\
\text { pathway }\end{array}$ & [34] \\
\hline RBL2H3 & $\begin{array}{l}\text { Rat basophilic } \\
\text { leukemia cells }\end{array}$ & $*$ & & $50 \mu \mathrm{M}$ & $4 \mathrm{~h}$ & $\begin{array}{l}\text { Increase calcium } \\
\text { level, Generation of } \\
\text { hydroperoxide, } \\
\text { Induce apoptosis via } \\
\text { Calcium-dependent } \\
\text { hydroperoxide accumulation, }\end{array}$ & [33] \\
\hline HL-60 & $\begin{array}{l}\text { Human } \\
\text { promyelocytic } \\
\text { leukemia }\end{array}$ & & * & $50 \mu \mathrm{M}$ & $24 \mathrm{~h}$ & $\begin{array}{l}\uparrow \text { Cell differentiation, } \\
\uparrow \text { Growth inhibition, } \\
\uparrow N B T \text { reducing activity, } \\
\uparrow \text { Expression of c-jun mRNA, } \\
\uparrow \text { c-jun protein, } \downarrow \text { Expression } \\
\text { of c-myc oncogene }\end{array}$ & {$[35]$} \\
\hline
\end{tabular}

(continued) 


\begin{tabular}{|c|c|c|c|c|c|c|c|}
\hline $\begin{array}{l}\text { Cell line } \\
\text { animal model }\end{array}$ & Specification & EPA & DHA & $\begin{array}{c}\text { Most } \\
\text { effective } \\
\text { dosage(s) }\end{array}$ & $\begin{array}{l}\text { Incubation } \\
\text { time(s) }\end{array}$ & Outcomes & Reference \\
\hline RBL2H3 & $\begin{array}{l}\text { Rat basophilic } \\
\text { leukemia cells }\end{array}$ & $*$ & $*$ & $\begin{array}{l}25,50,75 \\
\text { and } 100 \mu \mathrm{M}\end{array}$ & $1 \mathrm{~h}$ & $\begin{array}{l}\text { Suppress Th-2-seweked } \\
\text { allergic immune responces, } \\
\downarrow \text { Il-4 and IL-13 production, } \\
\downarrow \text { c-Fos expression, } \\
\downarrow \text { NF-AT expression, } \\
\downarrow \text { Phosphorylation of } \\
\text { extracellular signal-related } \\
\text { kinase, } \downarrow \text { Phosphorylation } \\
\text { of p38 mitogen-activated } \\
\text { protein kinase by DHA only. }\end{array}$ & [44] \\
\hline Jurkat & Human T cells & & $*$ & $10 \mu \mathrm{M}$ & $\begin{array}{c}3,6,12 \text {, and } \\
24 \mathrm{~h}\end{array}$ & $\begin{array}{l}\uparrow \text { Apoptosis, Cell cycle arrest } \\
\uparrow \text { Ceramide levels } \rightarrow \text { cdk } 2 \\
\text { inhibition } \rightarrow \uparrow P P a \text { and PP2A } \\
\text { activities } \rightarrow \downarrow R b \text { protein } \\
\text { phosphorylation }\end{array}$ & [43] \\
\hline Jurkat & Human T cells & & $*$ & $\begin{array}{c}60 \text { and } 90 \\
\mu \mathrm{M}\end{array}$ & $\begin{array}{l}48 \text { and } 24 \mathrm{~h} \text {, } \\
\text { respectively }\end{array}$ & $\begin{array}{l}\uparrow \text { Apoptosis } \\
\text { Caspase- } 3 \text { cleavage, PARP } \\
\text { degradation, and DNA } \\
\text { fragmentation } \\
\text { (via a phosphatase mediated } \\
\text { process involving PP1 and } \\
\text { PP2B) }\end{array}$ & {$[42]$} \\
\hline Jurkat & Human T cells & & $*$ & $15 \mu \mathrm{M}$ & $2 \mathrm{~h}$ & $\begin{array}{l}\downarrow \text { viability, Caspase-3 } \\
\text { activation, PP1-mediated }\end{array}$ & [7] \\
\hline HL-60 & $\begin{array}{l}\text { Human } \\
\text { promyelocytic } \\
\text { leukemia }\end{array}$ & $*$ & & $\begin{array}{c}20,35, \text { and } \\
70 \mu \mathrm{M}\end{array}$ & $48 \mathrm{~h}$ & $\begin{array}{l}\downarrow \text { proliferation, } \uparrow \text { Apoptosis } \\
\text { Depletion of intracellular } \\
\mathrm{Ca}^{++} \rightarrow \text { ER stress } \rightarrow \text { UPR } \\
\text { response }(\uparrow \text { protein levels of } \\
\text { phosphorylated Eukaryote } \\
\text { translation initiation factor } \\
\text { 2a, a UPR hallmark) }\end{array}$ & [9] \\
\hline SP 2/0 & $\begin{array}{l}\text { Mouse } \\
\text { myeloma cells }\end{array}$ & $*$ & $*$ & $\begin{array}{l}5,10,20, \\
\text { and } 40 \mu \mathrm{g} / \mathrm{ml}\end{array}$ & $24,48,72 \mathrm{~h}$ & $\begin{array}{l}\downarrow \text { proliferation, } \downarrow \text { Viability, } \\
\text { Superoxides, prostaglandin } \\
\text { and leukotriene-dependent }\end{array}$ & [27] \\
\hline T27A & $\begin{array}{l}\text { Mouse } \\
\text { leukemia cell } \\
\text { line }\end{array}$ & & $*$ & $\begin{array}{l}200-400 \mu \mathrm{M} \\
1 \mathrm{mM}\end{array}$ & NM & $\begin{array}{l}\text { Cytotoxicity } \\
\uparrow \text { tumor cell and lipid vesicle } \\
\text { premeability }\end{array}$ & [86] \\
\hline HL-60 & $\begin{array}{l}\text { Human } \\
\text { promyelocytic } \\
\text { leukemia }\end{array}$ & $*$ & & $\begin{array}{l}20,40,60 \\
\text { and } 80 \mu \mathrm{M}\end{array}$ & $24 \mathrm{~h}$ & $\begin{array}{l}\downarrow \text { proliferation, } \uparrow \text { Apoptosis, } \\
\text { Inhibition of topoisomerases } \\
\text { I and II and DNA } \\
\text { polymerases, Cell cycle } \\
\text { arrest at G1/S phase, } \uparrow \text { Cyclin } \\
\text { A and E protein levels }\end{array}$ & [87] \\
\hline
\end{tabular}

HSC, Hematopoetic Stem Cell; LSC, Leukemia Stem Cell; TAG, triacylglycerol; cdk2, cyclin-dependent kinase 2; Rb, retinoblastoma; NBT, Nitroblue Tetrazolium;

[29]. Conversely, in another study, DHA $(10 \mu \mathrm{M})$ prevented sphingosine-induced apoptosis in HL-60 cells after $24 \mathrm{~h}$ [30]. Following EPA $(30 \mu \mathrm{M})$ treatment, the cells showed increased caspase 3 and 9 activity without affecting caspase 8 activity or cell cycle progression [31]. Similar results have shown that EPA induces apoptosis via 
increased release of cytochrome c, activation of caspase-3 and enhanced mitochondrial-derived hydroperoxide (mitochondrial oxidative stress) [32]. To further investigate the mechanisms of EPA-induced apoptosis in mitochondria, RBL2H3 cells were treated with $50 \mu \mathrm{M}$ EPA for $4 \mathrm{~h}$. This significantly increased mitochondrial oxidative stress and calcium levels. The results showed that EPA can induce apoptosis via calcium-dependent hydroperoxide accumulation in the mitochondria [33].

Significant caspase-3 dependent apoptosis was observed following DHA $(50 \mu \mathrm{M})$ treatment in HL-60 cells. The use of cyclosporine-A as a mitochondrial permeability transition pore (MPTP) inhibitor did not inhibit caspase-3 activation or Bax translocation indicating that DHA may induce apoptosis through a Bax-independent pathway [34]. Treatment of HL-60 cells with $50 \mu \mathrm{M}$ DHA resulted in a concentration-dependent increase in cell differentiation and inhibited the cell growth. It also enhanced the nitro blue tetrazolium chloride (NBT) reducing activity as an indicator of cell differentiation. In addition, DHA $(50 \mu \mathrm{M})$ noticeably increased c-jun mRNA and protein levels whilst those of c-myc were markedly reduced [35].

\section{Apoptotic effects}

In vitro treatment of HL-60 and K-562 cells with EPA delayed cell cycle progression at G0/G1 but shortened the G2/M duration. It also induced significant necrosis in both cell lines by 19.6 and 4.4\%, respectively. Moreover, apoptosis was induced by EPA to a much greater extent in HL-60 cells which was mediated mainly by downregulating the expression of the bcl-2 signalling molecule, a major regulator of apoptosis [36, 37]). Similar results were reported in another study indicating that EPA $(40,60$, and $120 \mu \mathrm{M})$ can induce apoptosis in HL-60 cells but not in K562 cells independent of any of its effects on DNA fragmentation [38]. In addition, the apoptotic and necrotic effects of EPA have also been reported to be independent of both cyclooxygenase and lipooxygenase pathways and of lipid peroxidation [39]. Although the various EPA-sensitive and EPA-resistant leukemic cell lines express different levels of pro-apoptotic and antiapoptotic factors such as c-myc and Bcl-2, the differences in the expression of these factors do not account for its differential effects on apoptosis of different cells [40].

DHA from sources other than fish oil such as Crypthecodinium cohnii algae also have notable cell growth inhibiting properties in HL-60 cells. Algae-derived DHA halted HL-60 cell proliferation by delaying the cells in $\mathrm{G} 0 / \mathrm{G} 1$ in a concentration-dependent fashion $\left(\mathrm{IC}_{50}\right.$ of $74 \mu \mathrm{M}$ ) and significant apoptosis was observed at 24, 48, and $72 \mathrm{~h}$. This was associated with the inactivation of retinoblastoma $(\mathrm{Rb})$ protein and up-regulating the expression of E2F-6, a suppressor of transcription, and the pro-apoptotic molecule Bax [41]. High concentrations of DHA (60 and $90 \mu \mathrm{M}$ ) induced Jurkat cell apoptosis via caspase 3 activation, PARP degradation and DNA fragmentation.

Tautomycin and cypermethrin, two phosphatase inhibitors which inhibit protein phosphatase 1 (PP1) and protein phosphatase $2 \mathrm{~B}$ (PP2B) respectively, ablated the apoptotic effect of DHA implying a role for PP1 and PP2B in the induction of apoptosis [42]. The phosphatasedependent cytotoxic effect of DHA $(15 \mu \mathrm{M})$ has been also previously revealed in another study in which phosphatidic acid (PA), a specific PP1 inhibitor, reversed the DHA-induced apoptosis in Jurkat cells [7]. Repeated exposure to low concentrations of DHA $(10 \mu \mathrm{M})$ rapidly decreased Jurkat cell viability whilst a single exposure at the same concentration only induced cell cycle arrest. Overall, DHA-induced Jurkat cell apoptosis and loss of proliferation are believed to result from increased ceramide production which leads to the decreased cyclindependent kinase 2 (cdk2) activity as well as increased PP1 and PP2A activities. This leads to the inhibition of $\mathrm{Rb}$ phosphorylation and subsequent cell growth arrest [43]. An overview of the effects of EPA and DHA in hematological cancers is illustrated in Figure 2.

Integration of EPA and/or DHA into the plasma membrane of cells decreases the proportion of arachidonic acid (AA) and consequently the production of AA-derived inflammatory mediators. In turn, the production of the less inflammatory EPA- and DHA-derived eicosanoids is increased. On the other hand, the ability of these two FAs to decrease the activity of regulatory $\mathrm{T}$ cells, major regulators of immune responses to leukemic cells, skews the immune response to act against hematological malignancies [11]. DHA and EPA can also prevent allergic diseases by inhibiting Th2-driven immune responses. The results showed that they mitigate IL-4 and IL-13 production, decrease expression of c-Fos and NF-AT whilst inhibiting phosphorylation of the extracellular signal-related kinase [44].

\section{Epigenetic alterations}

DHA and EPA might also exert their biological effects via induction of epigenetic changes. These FAs are able to target the aberrant DNA methylation which is present in all types of cancers either across the whole DNA or at specific sites such as the non-coding regions of tumor suppressor genes [45]. Alteration of the extent of CpG methylation by PUFAs results in changes in the pattern of gene silencing and consequently the fate of target cell transcription. For example, EPA (100 $\mu \mathrm{M})$ demethylates specific $\mathrm{CpG}$ sites within the promoter region of the tumor suppressor gene CCAAT/enhancerbinding protein $(\mathrm{C} / \mathrm{EBP}) \delta$ in the $\mathrm{U} 937$ promonocytic cell line leading to its enhanced expression. In addition, EPA and to lower extents other PUFAs such as DHA, increased the expression of transcription factors including $\mathrm{C} / \mathrm{EBP} \beta$ and $\mathrm{C} / \mathrm{EBP} \delta$, PU.1 and c-Jun via similar epigenetic 
mechanisms [46]. Treatment of U937 cells with EPA (100 $\mu \mathrm{M})$ can also activate the Ras/ERK/C/EBP $\beta$ pathway via demethylating a $\mathrm{CpG}$ island within an intron of the H-Ras gene which drives monocyte differentiation [18]. Overall, the anti-proliferative and differentiation promoting effects of EPA on monocytic leukemia cells is driven, at least in part, by demethylation of promoter regions of genes involved in tumor suppression and differentiation. These effects are not restricted to EPA as they also occur, albeit at lower potencies, with other PUFAs. EPA-induced down-regulation of serglycin mRNA is involved in HL-60 cell differentiation in a similar manner to that evoked by retinoic acid (RA). Nonetheless, this effect was not via actions on c-myc expression, a known mechanism of RAinduced differentiation [39]. In contrast, EPA treatment of U-937-1 cells does not increase the expression of the monocytic lineage differentiation markers, CD36 and CD68, at least at the concentrations tested [26].

\section{Effects on calcium homeostasis}

DHA (10 and $20 \mu \mathrm{M}$ ) activates the $\mathrm{PLC} / \mathrm{IP}_{3}$ pathway and thereby increases intracellular calcium $\left(\mathrm{CA}^{++}\right)$ concentration and this has been implicated in DHAinduced apoptosis in U937 cells [47]. $\mathrm{Ca}^{++}$mobilization by DHA also decreases intracellular $\mathrm{pH}$ which might play a role in DHA-mediated apoptosis and anti-proliferative effects in human T cells [48]. Econazole is an antifungal agent which mobilizes the endoplasmic reticulum (ER) $\mathrm{Ca}^{++}$storage and blocks extracellular $\mathrm{Ca}^{++}$influx leading to a constant depletion of ER $\mathrm{Ca}^{++}$storage $[49,50]$. In HL-60 cells, EPA induces apoptosis via the induction of ER stress causing the unfolded protein response (UPR) pathway to be activated. EPA triggers ER-stress via the depletion of intracellular $\mathrm{Ca}^{++}$levels with a mechanism similar to that of econazole. In a similar fashion, EPA not only blocks trans-membrane $\mathrm{Ca}^{++}$influx via store-operated $\mathrm{Ca}^{++}$ channels (SOC), but also it increases $\mathrm{Ca}^{++}$release from the ER in an $\mathrm{IP}_{3}$-independent pathway. This will trigger the UPR response and finally lead to apoptosis [9].

\section{IN VIVO STUDIES}

Dietary supplementation of $1.5 \% \quad$ DHA (as an adjuvant to the nucleoside chemotherapy drug

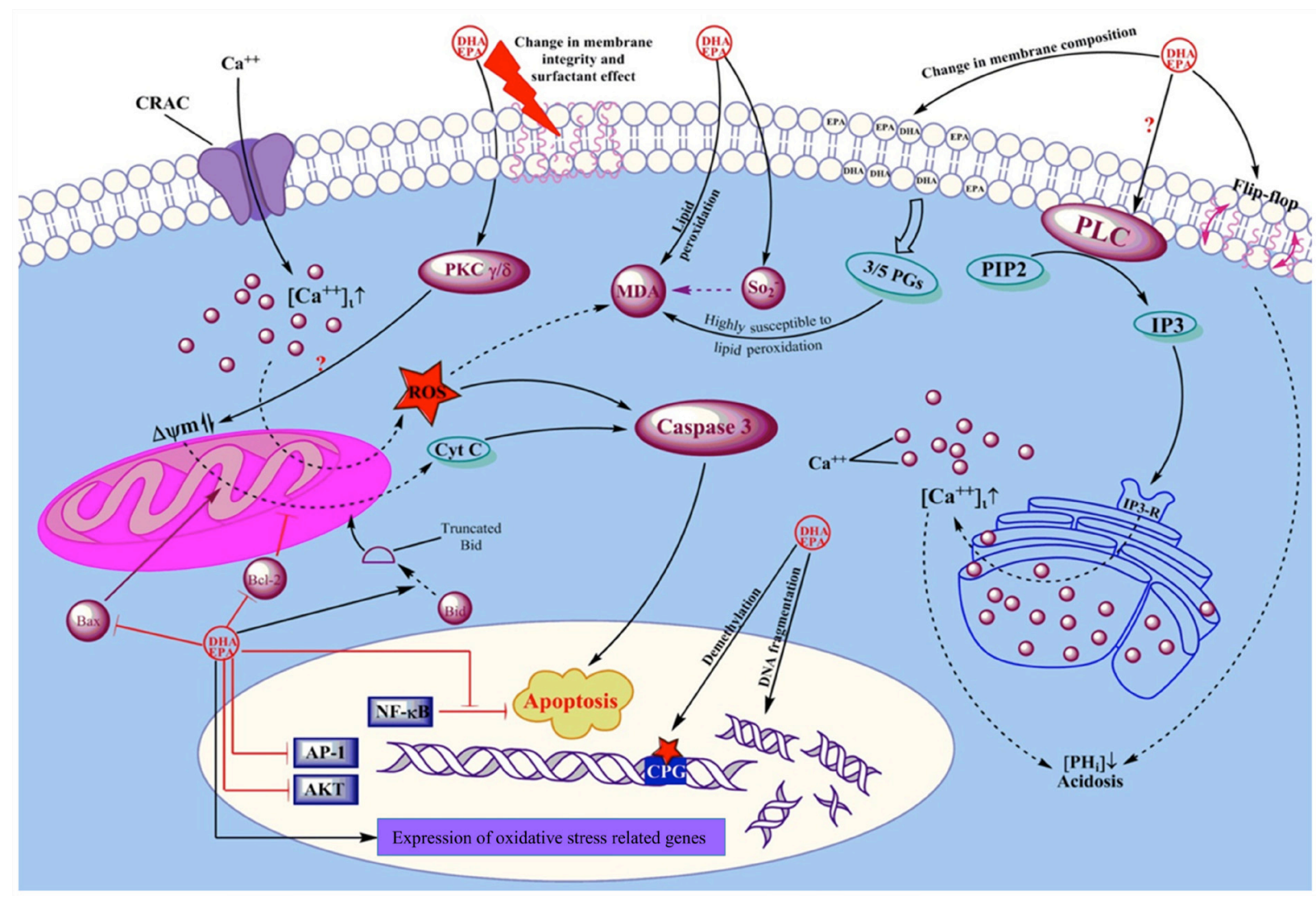

Figure 2: Schematic view of the mechanisms by which EPA and DHA affect leukemic cells. Arrows show positive effect or activation. Dead-end lines indicate a negative effect or blockade. Question marks show controversial results from different studies. EPA and DHA exert their effects on cancer cells via changing the membrane compisition, altering intracellular $\mathrm{Ca}^{++}$concentrations as well as intracellular $\mathrm{PH}$, modifying mitochondrial membrane premeability, changing cellular resistance to ROS damage, and by direct actions on DNA and gene expression. 
arabinosylcytosine, AraC) into a low-fat diet resulted in an average daily intake of $1.8 \mathrm{~g} \mathrm{DHA} / \mathrm{kg}^{\mathrm{BW}} /$ day and significantly increased the survival time of BDF1 mice bearing L1210 cell-induced leukemia from 12 days post leukemic cell injection to 33.3 days. In contrast, animals receiving higher amounts of DHA (4.5 g DHA $/ \mathrm{kg}^{\mathrm{BW}} /$ day) survived for 26.5 days after leukemia implementation [51]. This indicates that there is an optimal dose of DHA required to enhance survival time. Dietary EPA supplementation in experimental CML and AML C57/ BL6 mouse models has also been reported to target leukemia stem cells (LSCs) and decrease leukemia burden. Cyclooxygenase is necessary for the conversion of EPA into its metabolite $\triangle 12$-PGJ3. The inhibition of cyclooxygenase and hematopoietic prostaglandin D synthase (H-PGDS), by indomethacin and HQL-79 respectively, blocked the ability of EPA to attenuate cancer in CML-bearing animals. This suggests that $\triangle 12-\mathrm{PGJ} 3$ is the active agent for the EPA-induced effects which was confirmed with the re-establishment of the beneficial effects of EPA in indomethacin-treated mice following the administration of $\Delta 12-\mathrm{PGJ} 3$ [52].

\section{Effects of EPA/DHA on lymphoma cells}

In a study by Speizer et al. which investigated the effects of fish oil FAs including EPA and DHA on the activity of protein kinases from lymphoma cells and bovine brain it was revealed that these FAs can differentially alter the activities of protein kinase $\mathrm{C}$ and cAMP-dependent protein kinase and thus are able to act as intracellular second messengers [53]. It is interesting to note that although EPA and DHA have been shown to enhance the number and function of B lymphocytes under normal conditions via altering the membrane composition of the cells, they have no such effects on Raji, Ramos, and RPMI lymphoma cell lines at least at the tested concentration $(25 \mu \mathrm{M})$ and thus treatment with these two FAs does not promote cancer cell growth [54]. The suggested mechanism for this difference is the elongation of membrane-incorporated EPA and DHA into docosapentaenoic acid (DPA) which has been recently shown to substantially affect membrane properties [54]. EPA and more potently DHA were shown to readily incorporate into the plasma membrane of L5178Y lymphoma cells when added to the culture medium at concentrations higher than $10 \mu \mathrm{M}$. EPA and DHA also reduced the proliferation of the cells and increased the cytotoxicity of the chemotherapeutic agents including doxorubicin, dexamethasone, and mitomycin-C [55]. One study showed the necrosis and apoptosis inducing effects of EPA in two lymphoma cell lines, Raji and Ramos. The necrotic effect of EPA was reversed using different antioxidants without any effect on its apoptotic effects indicating a role for oxidative stress as a means of necrosis induction by EPA. In addition, protein synthesis was suggested to play roles in the EPA-induced apoptosis as this was prevented by the protein synthesis inhibitor cycloheximide [56]. Another study by the same group investigated the effects of EPA on the activities of different caspases and showed that the EPA-induced apoptosis in Ramos cells is mediated by a direct effect of EPA on the intrinsic pathway of apoptosis rather than interfering with cell cycle progression [57]. The use of triacsin C, an Acyl-CoA synthetase (ACS) inhibitor, has revealed the important role of ACS in the EPA-induced apoptosis. Inhibition of ACS by triacsin C caused a $90 \%$ decrease in the induction of apoptosis by EPA in the Ramos cell line. This can also, at least partly, explain the resistance of the U-698 cell line against EPA, since the U-698 cells express lower levels of ACS, compared to the EPA-sensitive cell lines such as Ramos [58].

A fish oil-supplemented diet has been shown to improve the metabolic parameters of dogs with lymphoblastic lymphoma. Such a diet resulted in increased plasma levels of DHA and EPA which was associated with lower levels of plasma lactic acid. This, in turn, increased the disease-free interval and survival time after doxorubicin chemotherapy [59]. The increased survival time and quality of life may not only have arisen from the direct anti-tumor activity of EPA and DHA, but also may be due to the cachexia-inhibiting effect of EPA, which was mediated by inhibition of cAMP in cancer cells both in mouse models and humans [60]. EPA, a key regulator of cyclin D1 synthesis, has been suggested to be of therapeutic potential in patients with mantle cell lymphoma since the main culprit in the pathogenesis and refractoriness of this type of malignancy is the elevated levels of cyclin D1 which is crucial in cell cycle progression from $\mathrm{G} 1$ to the $\mathrm{S}$ phase $[61,62]$. This notion is further supported by the results of a study by Cvetkovic et al. which showed lower levels of PUFAs in the serum of patients with non-Hodgkin lymphoma in comparison with healthy controls and the association of lower amounts of PUFAs in the serum of these patients with the clinical severity and aggressiveness of the disease [63]. In vitro treatment of YAC-1 lymphoma cell line with EPA has been shown to induce apoptosis in these cells via a caspase-3 independent pathway. Increases in the cellular ROS production as well as the accumulation of lipid droplets containing triacylglycerol in the cells were among the important changes observed in the YAC-1 cells treated with EPA [64].

\section{DRUG SENSITIZING EFFECTS}

Co-treatment of HL-60 leukemic cells with lipid preparations containing high concentrations of DHA and EPA did not improve the anti-proliferative effect of doxorubicin [23]. However, combining $\mathrm{As}_{2} \mathrm{O}_{3}$ and IFN- $\gamma$, a common chemotherapy for adult T-cell leukemia/lymphoma (ATL) patients, with emodin (a natural ROS-producing 
agent) and $10 \mu \mathrm{M}$ DHA resulted in a 100 -fold reduction in the dose of $\mathrm{As}_{2} \mathrm{O}_{3}$ required for the effective treatment of ATL. Emodin and DHA have been suggested to act via a synergistic action with $\mathrm{A}_{2} \mathrm{O}_{3}$ rather than having a direct antitumor action since treatment with emodin+DHA together did not induce significant effects on ATL. Potentiation of the cytostatic property of $\mathrm{As}_{2} \mathrm{O}_{3}$ by DHA was mainly attributed to its ROS generating abilities and down regulation of AP-1 and AKT expression which are both involved in cell survival [24]. $\mathrm{As}_{2} \mathrm{O}_{3}$, as an ROS-generating anti-cancer chemical, enhances ROS within malignant cells which, in turn, affects the co-administered DHA to form fatty acid hydroxides and hydroperoxides [65]. This potentiates the oxidizing actions of $\mathrm{As}_{2} \mathrm{O}_{3}$ which can be exploited to combat the malignant cells. In support of this, incorporation of 1 and $25 \mu \mathrm{M}$ DHA into an $\mathrm{As}_{2} \mathrm{O}_{3}$-based regimen not only extended its apoptotic effect to the $\mathrm{As}_{2} \mathrm{O}_{3}$-resistant HL-60 cell line but also significantly decreased the viability of leukemic cells when compared to DHA treatment alone [14].

On the other side, there are various defence mechanisms by which cells protect themselves against oxidative stress. Glutathione peroxidase $4(\mathrm{Gp}-\mathrm{x} 4)$ is the most important and the only enzyme which neutralizes lipid hydroperoxide, an important DHA oxidation end product, which mediates the cytotoxic effects of DHA [66]. In vivo treatment of $\mathrm{BDF} 1$ leukemic mice with oral DHA increased the cytostatic effect of AraC but also abolished drug toxicity-induced death. Interestingly, this effect was reversed when the intake of DHA was increased from $1.8 \mathrm{~g}$ to $4.5 \mathrm{~g} / \mathrm{kg}^{\mathrm{BW}} /$ day [51].

The biological effect of each member of PUFAs is specific to that member and differences between members of the same family of fatty acids have been reported. In this regard, treatment of HL-60 cells, bearing a BcrAbl translocation, with different concentrations of DHA $(25,50$ and $100 \mu \mathrm{M})$ resulted in higher sensitivity of the cells to the tyrosine kinase inhibitor imatinib mesylate, increased percentage of apoptotic cells and reduced viability. In contrast, EPA, a member of the same FA family, had no effect at any of the concentrations tested. Loss of membrane integrity as well as increased DNA fragmentation was suggested to be involved in these effects [65]. Pre-incubation of the lymphoma cell line L5178Y with $10 \mu \mathrm{M}$ and higher concentrations of DHA and EPA has been also shown to significantly increase the response of the cells to doxorubicin. The degree of unsaturation and chain length positively correlated with higher cytotoxic potencies of the tested FAs [55]. Cvetkovic et al. showed that the plasma phospholipid profile of patients with non-Hodgkin lymphoma influences response to chemotherapy in a manner that the plasma contents of PUFAs including EPA and DHA were lower in the patients who could not complete the chemotherapy course and in those with progressive disease compared to the patients in which the treatment period was successfully completed and remission was achieved [67].
Clioquinol, a recently used microbial agent in antitumor therapy, enhanced the apoptotic effect of DHA (100 $\mu \mathrm{M}$ ) in a human B-cell lymphoblastoid line (Raji) after a $72 \mathrm{~h}$ combination therapy. Downregulation of NF-kB as well as reducing the levels of cell survival signalling molecules including Akt and Bcl-2 are involved in this synergistic effect. Although clinoquinol treatment alone did not induce lipid peroxidation, pre-treatment with vitamin E blocked the synergistic effect of DHA and clioquinol, indicating that lipid peroxidation might play a key role in DHA-induced toxicity in Raji cells [68].

Pre-treatment of B-CLL and B-PLL-derived cell lines (EHEB, MEC-2 and JVM-2, respectively) with different concentrations of EPA and DHA decreased the tolerance of the cells against doxorubicine-, fludarabineand vincristine-induced toxicities resulting in decreased cell viability. The number of apoptotic cells also increased indicating that pre-treatment of the cells with DHA and EPA potentiated the cytotoxicity of the drugs via increasing lipid peroxidation, induction of ROS and inhibition of cell cycle at $\mathrm{G} 0 / \mathrm{M}$. Preventing oxidative stress using vitamin E did not reverse the drug-sensitizing effects suggesting the involvement of other unknown mechanisms [68]. DHA is also able to enhance doxorubicin sensitivity in P388 cells by elevating doxorubicin accumulation in cancer cells leading to increased cytotoxicity. A role for ROS was invoked as $50 \mu \mathrm{M}$ DHA enhanced superoxide dismutase (SOD) and catalase (CAT) activities [69]. The drug-sensitizing effects of EPA and DHA have been summarized in Table 2.

\section{DISCUSSION}

\section{Mechanisms of selective action}

Although structurally similar, EPA and DHA can differentially affect the biological activity of cells, at least partly, due to their different magnitude of effects on AAdependent processes within cells, as evidenced in U937 lymphoma cell line [70]. The long-term consumption of EPA has been shown to dramatically increase the EPA content of plasma, platelets and red blood cells with no effect on DHA content. This may suggests that extremely complex and distinct pathways may exist that regulate the metabolism of these two FAs [61]. Nonetheless, both EPA and DHA have selective actions on malignant cells with minor, if any, effects on normal cells [13, 14, 20, 24]. Therefore, the mechanisms responsible for these selective actions will not only help us design more effective anticancer treatments using omega-3 FAs but may also reveal new targets for chemotherapeutic agents. In contrast, cancer cell lines show variable levels of sensitivity to omega-3 FAs and some of them can tolerate treatment with these agents and are therefore resistant to them [40]. However, DHA and EPA can enhance the actions of other drugs to modulate the dysregulated activity/expression of 
oncogenic targets without having any significant effect on the target cells per se. An example of this is the ability of DHA and emodin to down-regulate the enhanced expression of AP-1 and increased AKT activity in HTLV-1 infected T cells [24]. Furthermore, since FAs synergize the oxidative effects of ROS-producing agents $[13,14]$ this may also elicit a potent anti-tumor action. However, the effectiveness of a single administration of DHA/EPA in the absence of ROS-producing agents indicates that this cannot be the only mechanism involved.

One of the mechanisms proposed for the anticancer effects of EPA and DHA is the induction of lipid peroxidation. The main intracellular mechanism which protects cells against lipid peroxidation is the enzyme GP-x4 and the variable sensitivity of different cell lines to DHA and EPA might reflect the differential expression of GP-x4 in various healthy and neoplastic cells. This will impact on the ability to protect against peroxidationinduced cellular damage [66].

The ability of different cells to metabolize EPA into its more effective metabolite $\triangle 12-\mathrm{PGJ} 3$ might also determine cell sensitivity to this FA [52]. Elevated expression of 3 acyl-CoA synthetases (ACSs) is observed in EPA-sensitive cell lines such as Ramos and Raji, giving these cells a greater ability to covert EPA into its active form EPA-CoA. In addition, some EPA-resistant cells such as U-698 have a limited ability to uptake PUFAs leading to reduced accumulation of cytosolic lipid droplets, a characteristic of responsive cells $[26,71]$. The differential expression of apoptosis regulating genes such as c-myc which drives the cell towards a programmed cell death response in those which express higher levels of c-myc (Ramos cell line) or towards necrotic cell death in those with less c-myc may explain why some neoplastic cells treated with EPA/DHA undergo apoptosis and others undergo necrosis [40].

DHA alters the composition of membrane microdomains replacing other fatty acids and reducing cholesterol and monoenoic FAs. This has been shown by evaluating the FA content of exfoliated microvesicles derived from DHA-treated leukemic cell lines. Thereby, DHA can induce a unique arrangement of lipid microdomains which might consequently determine the fate of membrane-bound signalling compartments to activate specific downstream pathways giving rise to different vital changes inside the cell [72].

\section{Feasibility of clinical usage}

The significant anti-cancer properties of omega-3 FAs especially EPA and DHA as well as their selective action and high safety profile $[73,74]$ suggest a promising clinical future. To date, studies have investigated the correlation between fish oil, as a rich source of omega-3 FAs, and other seafood consumption with a reduced risk of cancers. However, few clinical trials have been conducted to specifically study the effects of EPA and DHA on hematological malignancies. A clinical trial on 12 ALL and 6 AML patients investigated the effects of EPA as part of an energy and protein dense supplement. At the end of the trial, alleviation of cancer-induced weight loss and improvement of the overall conditions of adult and pediatric patients was observed. Decrease in the levels of circulating cytokines and acute phase proteins were attributed to the desirable effects of EPA [75].

The results of phase I and II clinical trials in patients with solid tumors have demonstrated that omega-3 FAs are safe and show promising results especially in patients in which the blood concentration of these FAs was raised significantly after treatment [76]. The recommended dose of EPA to improve cancerinduced cachexia is $1.5-2 \mathrm{~g} /$ day and side effects at this dose are minimal [77]; however, the benefit of increasing doses is unclear $[78,79]$. Although criticized by the fact that PUFAs increase oxidative stress and the production of lipid peroxyl radicals within cells predisposing them to oxidative damage [80], the consumption of PUFAs has been shown to be clinically safe. In one study, the safety of EPA oil was compared in vivo with the conventional commercial fish oil and the in vitro toxicity of EPA was assessed as well using the Ames mutagenicity test. The results showed that exposure of rats for 28 days at doses up to $2820 \mathrm{mg} / \mathrm{kg} /$ day does not cause any adverse effects on either of clinical, nutritional or anatomic pathology parameters of the animals. Moreover, EPA did not induce any mutations in the Ames test [81]. DHA is well-tolerated by humans even at doses up to $18 \mathrm{~g} /$ day [78]. In a study by Horrobin et al., the longterm intake of $12 \mathrm{~g} /$ day of ethyl-eicosapentaenoate as a dietary source of purified EPA by a patient suffering mantle cell lymphoma which resulted in a cumulative dose of $5 \mathrm{~kg}$ EPA within a 16-month period was shown to be safe without any side effects [61]. In vitro studies investigating the effects of DHA on different cancer cell lines have indicated $\mathrm{IC}_{50}$ concentrationsof $80-90 \mathrm{mM}$ [66] which is within the plasma and tissue concentration ranges of EPA/DHA and can be achieved clinically. Enhanced efficacy may be obtained using albumin-bound EPA or DHA to negate the effects of protein binding [40]. Moreover, it has been shown that dietary EPA, when it is metabolized, can produce sufficient amounts of $\Delta^{12}-\mathrm{PGJ}_{3}$ to induce apoptosis in leukemia cells [82]. A very recent study which investigated the effects of dietary EPA and DHA supplementation on the nutritional inflammatory status and long-term survival of patients with acute and chronic leukemia and lymphomas (Hodgkin and NonHodgkin lymphomas) receiving chemotherapy revealed that the consumption $2 \mathrm{~g}$ /day of fish oil (containing EPA and DHA) for 9 months resulted in greater reduction in the C-reactive protein (CRP) and $\mathrm{CRP}$ /albumin ratio in the patients receiving the supplement and chemotherapy in comparison to those receiving chemotherapy only. 
Table 2: The drug sensitizing effects of EPA and DHA in combination with conventional chemotherapeutic drugs used for the treatment of haematological malignancies

\begin{tabular}{|c|c|c|c|c|c|}
\hline DHA & EPA & Type of malignancy/model & Chemotherapy drug & $\begin{array}{c}\text { Effect and suggested } \\
\text { mechanism }\end{array}$ & Reference \\
\hline$*$ & \multirow[t]{3}{*}{$*$} & Multiple myeloma cell lines & Bortezomib (Valcane) & NM & [20] \\
\hline$*$ & & $\begin{array}{l}\text { arsenic trioxide-resistant } \\
\text { leukemic HL-60 cells } \\
\text { (as well as solid tumor cell lines) }\end{array}$ & $\begin{array}{l}\mathrm{As}_{2} \mathrm{O}_{3} \\
\text { [A ROS inducing } \\
\text { chemotherapy agent] }\end{array}$ & $\begin{array}{l}\uparrow \text { Bax expression } \\
\uparrow \text { Caspase } 3 \text { activation } \\
\uparrow R O S \text { production and } \\
\text { lipid peroxidation } \\
\text { [Selective effect] }\end{array}$ & {$[13,14]$} \\
\hline$*$ & & $\begin{array}{l}\text { HTLV-I-immortalized } \\
\text { and -transformed T cells } \\
\text { (a model of ATL) }\end{array}$ & $\mathrm{As}_{2} \mathrm{O}_{3}$ & $\begin{array}{l}\uparrow \text { Cell death, } \\
\downarrow \text { Proliferation, } \uparrow \text { ROS } \\
\text { production } \\
\downarrow \text { mitochondrial } \\
\text { membrane potential } \\
\text { Down regulation } \\
\text { of AP-1 and AKT } \\
\text { expression } \\
\text { [Selective; only } \\
\text { marginal effect on } \\
\text { healthy PBMCS] }\end{array}$ & [24] \\
\hline \multirow[t]{2}{*}{$*$} & & $\begin{array}{l}\text { BDF1 mice bearing L1210 } \\
\text { leukemic cells }\end{array}$ & $\mathrm{AraC}$ & $\begin{array}{l}\uparrow \text { Survival time in } \\
\downarrow \text { Drug-toxicity } \\
\text { induced death }\end{array}$ & {$[51]$} \\
\hline & $*$ & HL-60 myeloid leukemia cell line & TPA & 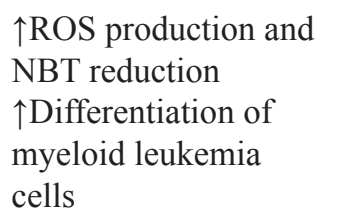 & [25] \\
\hline$*$ & & Bcr-Abl expressing HL-60 cells & Imatinib & $\begin{array}{l}\downarrow \text { Viability, } \uparrow \text { Apoptosis, } \\
\downarrow \text { Membrane integrity, } \\
\uparrow \text { DNA fragmentation }\end{array}$ & [65] \\
\hline$*$ & $*$ & $\begin{array}{l}\text { B-CLL-derived cell lines EHEB } \\
\text { and MEC-2 } \\
\text { B-PLL-derived cell line JVM-2 }\end{array}$ & $\begin{array}{l}\text { Doxorubicin } \\
\text { Fludarabine } \\
\text { Vincristine }\end{array}$ & $\begin{array}{l}\downarrow \text { Viability, } \uparrow \text { Apoptosis } \\
\uparrow \text { ROS production } \\
\uparrow \text { Lipid peroxidation }\end{array}$ & [85] \\
\hline$*$ & & T27A (murine leukemia cell line) & methotrexate & $\begin{array}{l}\text { Growth inhibition via } \\
\text { synergistic effect }\end{array}$ & \\
\hline
\end{tabular}

$\mathrm{As}_{2} \mathrm{O}_{3}$, Arsenic trioxide; ATL, Acute T-cell Leukemia; AraC, Arabinosylcytosine; TPA, 12-O-tetradecanoylphorbol-13acetate; NM, not mentioned

This significantly prolonged the overall survival time of the patients [83]. The results of these studies all together may give rise to the notion that supplementation with PUFAs may not only cause direct anti-tumor effects in the context of haematological malignancies, but also it may improve the response to treatment and the side effects of conventional chemotherapy via attenuating the inflammatory status of the patients, thus playing a dual role in improving the treatment outcome of patients with haematological malignancies.

\section{CONCLUSION}

Based on the previous findings, conducting studies comparing different cell lines in terms of resistance and sensitivity to EPA/DHA is recommended. This can help pointing out the differences which might serve as the target for the action of EPA/DHA. Moreover, considering the diverse effects observed with high and low concentrations of these two FAs, determining the optimal dietary/non-dietary supplementation of PUFAs into chemotherapy regimens is 
also essential. Delineating the precise mechanism of action of EPA and DHA in inducing selective cancer cell death; epigenetic effects on tumor suppressor genes, enhancing ROS production or effects on lipid peroxidation will enable better targeting of cancers using these drugs. While most in vitro studies conducted to date focus on the direct effects of PUFAs, in vivo studies utilising the synergistic actions of EPA and DHA may shed light on the indirect mechanisms of these agents such as on immune cell and cytokine regulation which might inhibit the growth of cancer cells. Rapid screening of primary cancer cells exposed to DHA and EPA ex vivo may also define the correct patient and combination of drugs required for optimal therapy enhancing our options for personalised or precision medicine.

\section{CONFLICTS OF INTEREST}

The authors declare no conflicts of interest.

\section{REFERENCES}

1. Calder PC. Mechanisms of action of (n-3) fatty acids. The Journal of nutrition. 2012; 142:592S-9S.

2. Acids UF. Nutritional and physiological significance. The Report of the British Nutrition Foundation's Task Force, Chapman and Hall, London. 1992.

3. Geleijnse JM, Giltay EJ, Grobbee DE, Donders AR, Kok FJ. Blood pressure response to fish oil supplementation: metaregression analysis of randomized trials. LWW; 2002.

4. von Schacky C. Omega-3 fatty acids: antiarrhythmic, proarrhythmic or both? current opinion in Clinical Nutrition \& Metabolic Care. 2008; 11:94-9.

5. Demel R, Van Kessel WG, van Deenen L. The properties of polyunsaturated lecithins in monolayers and liposomes and the interactions of these lecithins with cholesterol. Biochimica et Biophysica Acta (BBA)-Biomembranes. 1972; 266:26-40.

6. Tomobe YI, Morizawa $\mathrm{K}$, Tsuchida $\mathrm{M}$, Hibino $\mathrm{H}$, Nakano Y, Tanaka Y. Dietary docosahexaenoic acid suppresses inflammation and immunoresponses in contact hypersensitivity reaction in mice. Lipids. 2000; 35:61-9.

7. Siddiqui RA, Jenski LJ, Wiesehan JD, Hunter MV, Kovacs RJ, Stillwell W. Prevention of docosahexaenoic acid-induced cytotoxicity by phosphatidic acid in jurkat leukemic cells: the role of protein phosphatase-1. Biochimica et Biophysica Acta - Molecular Cell Research. 2001; 1541:188-200.

8. Moyad MA. An introduction to dietary/supplemental omega-3 fatty acids for general health and prevention: Part II. Urologic Oncology: Seminars and Original Investigations. 2005; 23:36-48.

9. Slagsvold JE, Pettersen CHH, Follestad T, Krokan HE, Schonberg SA. The antiproliferative effect of EPA in HL60 cells is mediated by alterations in calcium homeostasis. Lipids. 2009; 44:103-13.

10. Song EA, Kim H. Docosahexaenoic acid induces oxidative DNA damage and apoptosis, and enhances the chemosensitivity of cancer cells. International Journal of Molecular Sciences. 2016; 17:1257.

11. Betiati DSB, de Oliveira PFD, Camargo CQ, Nunes EA, de Moraes EBS, Trindade EB. effects of omega-3 fatty acids on regulatory t cells in hematologic neoplasms. Revista Brasileira de Hematologia e Hemoterapia. 2013; 35:119-25.

12. Asghari MH, Moloudizargari M, Ghobadi E, Fallah M, Abdollahi M. Melatonin as a multifunctional anti-cancer molecule: Implications in gastric cancer. Life Sciences. 2017; 185:38-45.

13. Baumgartner M, Sturlan S, Roth E, Wessner B, BachleitnerHofmann T. Enhancement of arsenic trioxide-mediated apoptosis using docosahexaenoic acid in arsenic trioxideresistant solid tumor cells. International Journal of Cancer. 2004; 112:707-12.

14. Sturlan S, Baumgartner M, Roth E, Bachleitner-Hofmann T. Docosahexaenoic acid enhances arsenic trioxide-mediated apoptosis in arsenic trioxide-resistant HL-60 cells. Blood. 2003; 101:4990-7.

15. Fan YY, McMurray DN, Ly LH, Chapkin RS. Dietary (n-3) polyunsaturated fatty acids remodel mouse T-cell lipid rafts. The Journal of nutrition. 2003; 133:1913-20.

16. Stulnig TM, Huber J, Leitinger N, Imre EM, Angelisová $\mathrm{P}$, Nowotny P, Waldhausl W. Polyunsaturated eicosapentaenoic acid displaces proteins from membrane rafts by altering raft lipid composition. Journal of Biological Chemistry. 2001; 276:37335-40.

17. Arita K, Kobuchi H, Utsumi T, Takehara Y, Akiyama J, Horton AA, Utsumi K. Mechanism of apoptosis in HL-60 cells induced by n-3 and n-6 polyunsaturated fatty acids. Biochemical Pharmacology. 2001; 62:821-8.

18. Ceccarelli V, Nocentini G, Billi M, Racanicchi S, Riccardi C, Roberti R, Grignani F, Binaglia L, Vecchini A. Eicosapentaenoic acid activates RAS/ERK/C/EBP $\beta$ pathway through $\mathrm{H}$-ras intron $1 \mathrm{CpG}$ island demethylation in U937 leukemia cells. PLoS ONE. 2014; 9.

19. Siddiqui RA, Harvey KA, Xu Z, Bammerlin EM, Walker C, Altenburg JD. Docosahexaenoic acid: a natural powerful adjuvant that improves efficacy for anticancer treatment with no adverse effects. BioFactors. 2011; 37:399-412.

20. Abdi J, Garssen J, Faber J, Redegeld FA. Omega-3 fatty acids, EPA and DHA induce apoptosis and enhance drug sensitivity in multiple myeloma cells but not in normal peripheral mononuclear cells. Journal of Nutritional Biochemistry. 2014; 25:1254-62.

21. Khaddaj-Mallat R, Morin C, Rousseau É. Novel n-3 PUFA monoacylglycerides of pharmacological and medicinal interest: anti-inflammatory and anti-proliferative effects. European Journal of Pharmacology. 2016; 792:70-7. 
22. Rudolph I, Kelley D, Klasing K, Erickson KL. Regulation of cellular differentiation and apoptosis by fatty acids and their metabolites. Nutrition Research. 2001; 21:381-93.

23. Bodkowski R, Patkowska-Sokola B, Filip-Psurska B, Kempinska K, Wietrzyk JA, Czyz K, WalisiewiczNiedbalska W, Usydus Z. Evaluation of the antiproliferative activity of natural lipid preparations against tumor cell lines. Journal of East Asian Studies. 2014; 13:257-66.

24. Brown M, Bellon M, Nicot C. Emodin and DHA potently increase arsenic trioxide interferon-alpha-induced cell death of HTLV-I-transformed cells by generation of reactive oxygen species and inhibition of Akt and AP-1. Blood. 2007; 109:1653-9.

25. Chien CC, Wu MS, Shen SC, Yang LY, Wu WS, Chen YC. Arachidonic acid enhances TPA-induced differentiation in human leukemia HL-60 cells via reactive oxygen speciesdependent ERK activation. Prostaglandins Leukotrienes and Essential Fatty Acids. 2013; 88:289-98.

26. Finstad HS, Drevon CA, Kulseth MA, Synstad AV, Knudsen E, Kolset SO. Cell proliferation, apoptosis and accumulation of lipid droplets in U937-1 cells incubated with eicosapentaenoic acid. Biochemical Journal. 1998; 336:451-9.

27. Sravan Kumar G, Das UN. Cytotoxic action of alphalinolenic and eicosapentaenoic acids on myeloma cells in vitro. Prostaglandins, leukotrienes, and essential fatty acids. 1997; 56:285-93.

28. Gillis RC, Daley BJ, Enderson BL, Karlstad MD. Eicosapentaenoic acid and $\gamma$-linolenic acid induce apoptosis in HL-60 cells. Journal of Surgical Research. 2002; 107:145-53.

29. Guièze R, Gyan E, Tournilhac O, Halty C, Veyrat-Masson R, Akil S, Berger M, Hérault O, Callanan M, Bay JO. Docosahexaenoic acid induces apoptosis in primary chronic lymphocytic leukemia cells. Hematology Reports. 2015; 7:91-2.

30. Kishida E, Yano M, Kasahara M, Masuzawa Y. Distinctive inhibitory activity of docosahexaenoic acid against sphingosine-induced apoptosis. Biochimica Et Biophysica Acta-Lipids and Lipid Metabolism. 1998; 1391:401-8.

31. Heimli H, Giske C, Naderi S, Drevon CA, Hollung K. Eicosapentaenoic acid promotes apoptosis in Ramos cells via activation of caspase-3 and -9. Lipids. 2002; 37:797-802.

32. Koumura T, Nakamura C, Nakagawa Y. Involvement of hydroperoxide in mitochondria in the induction of apoptosis by the eicosapentaenoic acid. Free Radical Research. 2005; 39:225-35.

33. Koumura T, Nakamura C, Nakagawa Y. Role of calciuminduced mitochondrial hydroperoxide in induction of apoptosis of RBL2H3 cells with eicosapentaenoic acid treatment. Free Radical Research. 2005; 39:1083-9.

34. Miura Y, Takahara K, Murata Y, Utsumi K, Tada M, Takahata K. Docosahexaenoic acid induces apoptosis via the bax-independent pathway in HL-60 cells. Bioscience, Biotechnology and Biochemistry. 2004; 68:2415-7.

35. Ishigamori $H$, Hosokawa $M$, Kohno $H$, Tanaka $T$, Miyashita K, Takahashi K. Docosahexaenoic acidcontaining phosphatidylethanolamine enhances HL-60 cell differentiation by regulation of c-jun and c-myc expression. Molecular and Cellular Biochemistry. 2005; 275:127-33.

36. Chiu LC, Wan JM. Induction of apoptosis in HL-60 cells by eicosapentaenoic acid (EPA) is associated with downregulation of bcl-2 expression. Cancer Lett. 1999; 145:17-27.

37. Moloudizargari M, Asghari MH, Ghobadi E, Fallah M, Rasouli S, Abdollahi M. Autophagy, its mechanisms and regulation: implications in neurodegenerative diseases. Ageing Res Rev. 2017; 40:64-74.

38. Chiu LC, Wan JM, Ooi VE. Induction of apoptosis by dietary polyunsaturated fatty acids in human leukemic cells is not associated with DNA fragmentation. International journal of oncology. 2000; 17:789-96.

39. Finstad HS, Kolset SO, Holme JA, Wiger R, Östlund Farrants AK, Blomhoff R, Drevon CA. Effect of n-3 and n-6 fatty acids on proliferation and differentiation of promyelocytic leukemic HL-60 cells. Blood. 1994; 84:3799-809.

40. Finstad HS, Wik Myhrstad MC, Heimli H, Lomo J, Kiil Blomhoff H, Kolset SO, Drevon CA. Multiplication and death-type of leukemia cell lines exposed to very long-chain polyunsaturated fatty acids. Leukemia. 1998; 12:921-9.

41. Chiu LC, Wong EY, Ooi VE. Docosahexaenoic acid modulates different genes in cell cycle and apoptosis to control growth of human leukemia HL-60 cells. International journal of oncology. 2004; 25:737-44.

42. Siddiqui RA, Jenski LJ, Neff K, Harvey K, Kovacs RJ, Stillwell W. Docosahexaenoic acid induces apoptosis in jurkat cells by a protein phosphatase-mediated process. Biochimica et Biophysica Acta - Molecular Cell Research. 2001; 1499:265-75.

43. Siddiqui RA, Jenski LJ, Harvey KA, Wiesehan JD, Stillwell W, Zaloga GP. Cell-cycle arrest in jurkat leukaemic cells: a possible role for docosahexaenoic acid. Biochemical Journal. 2003; 371:621-9.

44. Jin M, Park S, Park BK, Choi JJ, Yoon SJ, Yang M, Pyo MY. Eicosapentaenoic acid and docosahexaenoic acid suppress Th2 cytokine expression in RBL-2H3 basophilic leukemia cells. Journal of Medicinal Food. 2014; 17:198-205.

45. Jones PA, Baylin SB. The epigenomics of cancer. Cell. 2007; 128:683-92.

46. Ceccarelli V, Racanicchi S, Martelli MP, Nocentini G, Fettucciari K, Riccardi C, Marconi P, Di Nardo P, Grignani F, Binaglia L, Vecchini A. Eicosapentaenoic acid demethylates a single $\mathrm{CpG}$ that mediates expression of tumor suppressor CCAAT/enhancer-binding protein delta in U937 leukemia cells. Journal of Biological Chemistry. 2011; 286:27092-102. 
47. Aires V, Hichami A, Filomenko R, Ple A, Rebe C, Bettaieb A, Khan NA. Docosahexaenoic acid induces increases in $\mathrm{Ca} 2+$ (i) via inositol 1,4,5-triphosphate production and activates protein kinase $\mathrm{C}$ gamma and -delta via phosphatidylserine binding site: implication in apoptosis in U937 cells. Molecular Pharmacology. 2007; 72:1545-56.

48. Aires V, Hichami A, Moutairou K, Khan NA. Docosahexaenoic acid and other fatty acids induce a decrease in $\mathrm{pH} \mathrm{i}$ in jurkat t-cells. British Journal of Pharmacology. 2003; 140:1217-26.

49. Gamberucci A, Fulceri R, Benedetti A, Bygrave FL. On the mechanism of action of econazole, the capacitative calcium inflow blocker. Biochemical and biophysical research communications. 1998; 248:75-7.

50. Jan CR, Ho CM, Wu SN, Tseng CJ. Multiple effects of econazole on calcium signaling: depletion of thapsigarginsensitive calcium store, activation of extracellular calcium influx, and inhibition of capacitative calcium entry. Biochimica et Biophysica Acta (BBA)-Molecular Cell Research. 1999; 1448:533-42.

51. Cha MC, Aldred A, Stewart C, Meckling KA. Dietary docosahexaenoic acid levels influence the outcome of arabinosylcytosine chemotherapy in L1210 leukemic mice. Nutrition and Cancer. 2002; 44:175-81.

52. Finch ER, Kudva AK, Quickel MD, Goodfield LL, Kennett MJ, Whelan J, Paulson RF, Prabhu KS. Chemopreventive effects of dietary eicosapentaenoic acid supplementation in experimental myeloid leukemia. Cancer Prevention Research. 2015; 8:989-99.

53. Speizer LA, Watson MJ, Brunton LL. Differential effects of omega-3 fish oils on protein kinase activities in vitro. American Journal of Physiology-Endocrinology and Metabolism. 1991; 261:E109-E14.

54. Harris M, Kinnun JJ, Kosaraju R, Leng X, Wassall SR, Shaikh SR. Membrane disordering by eicosapentaenoic acid in B lymphomas is reduced by elongation to docosapentaenoic acid as revealed with solid-state nuclear magnetic resonance spectroscopy of model membranes. The Journal of nutrition. 2016; 146:1283-9.

55. Kinsella JE, Black JM. Effects of polyunsaturated fatty acids on the efficacy of antineoplastic agents toward L5178Y lymphoma cells. Biochemical pharmacology. 1993; 45:1881-7.

56. Heimli H, Finstad HS, Drevon CA. Necrosis and apoptosis in lymphoma cell lines exposed to eicosapentaenoic acid and antioxidants. Lipids. 2001; 36:613.

57. Heimli H, Giske C, Naderi S, Drevon CA, Hollung K. Eicosapentaenoic acid promotes apoptosis in ramos cells via activation of caspase-3 and-9. Lipids. 2002; 37:797.

58. Heimli H, Hollung K, Drevon CA. Eicosapentaenoic acidinduced apoptosis depends on acyl CoA-synthetase. Lipids. 2003; 38:263.

59. Ogilvie GK, Fettman MJ, Mallinckrodt $\mathrm{CH}$, Walton JA, Hansen RA, Davenport DJ, Gross KL, Richardson KL, Rogers Q, Hand MS. Effect of fish oil, arginine, and doxorubicin chemotherapy on remission and survival time for dogs with lymphoma. Cancer. 2000; 88:1916-28.

60. Tisdale MJ. Inhibition of lipolysis and muscle protein degradation by EPA in cancer cachexia. Nutrition. 1996; 12:S31-S3.

61. Horrobin D, Fokkema MR, Muskiet FA. The effects on plasma, red cell and platelet fatty acids of taking $12 \mathrm{~g}$ /day of ethyl-eicosapentaenoate for 16 months: dihomogammalinolenic, arachidonic and docosahexaenoic acids and relevance to Inuit metabolism. Prostaglandins, leukotrienes and essential fatty acids. 2003; 68:301-4.

62. Horrobin DF. A low toxicity maintenance regime, using eicosapentaenoic acid and readily available drugs, for mantle cell lymphoma and other malignancies with excess cyclin D1 levels. Medical hypotheses. 2003; 60:615-23.

63. Cvetković Z, Vučić V, Cvetković B, Petrović M, RistićMedić D, Tepšić J, Glibetić M. Abnormal fatty acid distribution of the serum phospholipids of patients with non-Hodgkin lymphoma. Annals of hematology. 2010; $89: 775-82$.

64. Puertollano MA, de Pablo MA, Alvarez de Cienfuegos G. Polyunsaturated fatty acids induce cell death in YAC-1 lymphoma by a caspase-3-independent mechanism. Anticancer research. 2002; 23:3905-10.

65. de Lima TM, Amarante-Mendes GP, Curi R. Docosahexaenoic acid enhances the toxic effect of imatinib on Bcr-Abl expressing HL-60 cells. Toxicology in vitro. 2007; 21:1678-85.

66. Ding WQ, Lind SE. Phospholipid hydroperoxide glutathione peroxidase plays a role in protecting cancer cells from docosahexaenoic acid-induced cytotoxicity. Molecular Cancer Therapeutics. 2007; 6:1467-74.

67. Cvetković Z, Vučić V, Cvetković B, Karadžić I, Ranić M, Glibetić M. Distribution of plasma fatty acids is associated with response to chemotherapy in non-Hodgkin's lymphoma patients. Medical Oncology. 2013; 30:741.

68. Ding WQ, Liu B, Vaught JL, Palmiter RD, Lind SE. Clioquinol and docosahexaenoic acid act synergistically to kill tumor cells. Molecular Cancer Therapeutics. 2006; $5: 1864-72$.

69. Liu QY, Tan BKH. Effects of cis-unsaturated fatty acids on doxorubicin sensitivity in P388/DOX resistant and P388 parental cell lines. Life Sciences. 2000; 67:1207-18.

70. Obajimi O, Black KD, MacDonald DJ, Boyle RM, Glen I, Ross BM. Differential effects of eicosapentaenoic and docosahexaenoic acids upon oxidant-stimulated release and uptake of arachidonic acid in human lymphoma U937 cells. Pharmacological research. 2005; 52:183-91.

71. Finstad HS, Dyrendal H, Wik Myhrstad MC, Heimli H, Drevon CA. Uptake and activation of eicosapentaenoic acid are related to accumulation of triacylglycerol in Ramos cells dying from apoptosis. Journal of Lipid Research. 2000; 41:554-63. 
72. Williams EE, Jenski LJ, Stillwell W. Docosahexaenoic acid (DHA) alters the structure and composition of membranous vesicles exfoliated from the surface of a murine leukemia cell line. Biochimica et Biophysica Acta - Biomembranes. 1998; 1371:351-62.

73. Lien EL. Toxicology and safety of DHA. Prostaglandins, leukotrienes and essential fatty acids. 2009; 81:125-32.

74. Maki KC, Yurko-Mauro K, Dicklin MR, Schild AL, Geohas JG. A new, microalgal DHA-and EPA-containing oil lowers triacylglycerols in adults with mild-to-moderate hypertriglyceridemia. Prostaglandins, Leukotrienes and Essential Fatty Acids (PLEFA). 2014; 91:141-8.

75. Bayram I, Erbey F, Celik N, Nelson JL, Tanyeli A. The use of a protein and energy dense eicosapentaenoic acid containing supplement for malignancy-related weight loss in children. Pediatric Blood and Cancer. 2009; 52:571-4.

76. Calviello G, Serini S, Piccioni E, Pessina G. Antineoplastic Effects of N-3 Polyunsaturated fatty acids in combination with drugs and radiotherapy: preventive and therapeutic strategies. Nutrition and Cancer-an International Journal. 2009; 61:287-301.

77. Colomer R, Moreno-Nogueira JM, Garcia-Luna PP, GarciaPeris P, Garcia-de-Lorenzo A, Zarazaga A, Quecedo L, del Llano J, Usán L, Casimiro C. n-3 Fatty acids, cancer and cachexia: a systematic review of the literature. British Journal of Nutrition. 2007; 97:823-31.

78. Burns CP, Halabi S, Clamon G, Kaplan E, Hohl RJ, Atkins JN, Schwartz MA, Wagner BA, Paskett E. Phase II study of high-dose fish oil capsules for patients with cancer-related cachexia. Cancer. 2004; 101:370-8.

79. Fearon K, Von Meyenfeldt M, Moses A, Van Geenen R, Roy A, Gouma D, Giacosa A, Van Gossum A, Bauer J, Barber MD, Aaronson NK, Voss AC, Tisdale MJ. Effect of a protein and energy dense N-3 fatty acid enriched oral supplement on loss of weight and lean tissue in cancer cachexia: a randomised double blind trial. Gut. 2003; 52:1479-86.

80. Obajimi O, Black KD, Glen I, Ross BM. Antioxidant modulation of oxidant-stimulated uptake and release of arachidonic acid in eicosapentaenoic acid-supplemented human lymphoma U937 cells. Prostaglandins, leukotrienes and essential fatty acids. 2007; 76:65-71.

81. Belcher LA, MacKenzie SA, Donner M, Sykes GP, Frame SR, Gillies PJ. Safety assessment of EPA-rich triglyceride oil produced from yeast: genotoxicity and 28-day oral toxicity in rats. Regulatory Toxicology and Pharmacology. 2011; 59:53-63.

82. Tsikas D, Stichtenoth DO. Dietary eicosapentaenoic acid (EPA) to produce antileukemic cyclopentenone prostaglandin J3? Blood. 2012; 119:2967-8.

83. Chagas TR, Borges D, Oliveira P, Mocellin MC, Barbosa AM, Camargo C, Del Moral JÂG, Poli A, Calder PC, Trindade EBSM, Nunes EA. Oral fish oil positively influences nutritional-inflammatory risk in patients with haematological malignancies during chemotherapy with an impact on long-term survival: a randomised clinical trial. Journal of Human Nutrition and Dietetics. 2017;30:681-692.

84. Ambika Devi M, Das NP. Antiproliferative effect of polyunsaturated fatty acids and interleukin-2 on normal and abnormal human lymphocytes. Experientia. 1994; 50:489-92.

85. Fahrmann JF, Hardman WE. Omega 3 fatty acids increase the chemo-sensitivity of B-CLL-derived cell lines EHEB and MEC-2 and of B-PLL-derived cell line JVM-2 to anticancer drugs doxorubicin, vincristine and fludarabine. Lipids in Health and Disease. 2013; 12.

86. Stillwell W, Ehringer W, Jenski LJ. Docosahexaenoic acid increases permeability of lipid vesicles and tumor cells. Lipids. 1993; 28:103-8.

87. Yonezawa Y, Hada T, Uryu K, Tsuzuki T, Eitsuka T, Miyazawa T, Murakami-Nakai C, Yoshida H, Mizushina Y. Inhibitory effect of conjugated eicosapentaenoic acid on mammalian DNA polymerase and topoisomerase activities and human cancer cell proliferation. Biochemical Pharmacology. 2005; 70:453-60. 